\title{
MUSIKER UNTER DRUCK: ZENSORISCHE MASSNAHMEN IM IRAKKRIEG
}

\author{
Christiane Rohr
}

Der Krieg im Irak war von Anfang an heftig umstritten. Je lauter die Proteste wurden und je näher der Tag der offiziellen Kriegserklärung rückte, desto vehementer versuchten die US-amerikanischen Medien, die Meinung der vermeintlichen Gegner im eigenen Land zu unterdrücken. Besonders wichtig schien es dabei, Filmschaffende und Musiker zum Schweigen zu bringen. Künstler, die sich mit den Plänen des Bush-Kabinetts nicht einverstanden zeigten, wurden als »unamerikanisch« gebrandmarkt und ihre Arbeit in unverhältnismäßigem Ausmaß durch die Medien boykottiert. Viele andersdenkende Stars wagten kaum noch, sich zum Krieg zu äußern. Wer sich nicht abschrecken ließ, sah sich massivem Druck ausgesetzt. Im Folgenden soll versucht werden, einen Einblick in die Geschehnisse und das Medienumfeld des Irakkonflikts zu geben.

\section{Mit dem Militär gegen Spearhead}

Als politisch aktive Musiker stellten Spearhead einen Remix ihres nach dem 11. September entstandenen Tracks »Bomb The World« auf ihre Website. Der prominente Chorus und die eigentliche Message des Songs lauten: »We can bomb the world to pieces, but we can't bomb it into peace «. Bei australischen und dänischen Radiostationen lief der Song auf Heavy Rotation, in den USA jedoch wurde er - wie sämtliche anderen Protest-Songs weitgehend ignoriert.

Kurz vor dem Ausbruch des Krieges spielte die Band auf Anti-KriegsKonzerten wie z.B. am 15. März 2003 in San Francisco. Am Tag nach dem Konzert erhielt die Mutter von Radioactive, einem Mitglied der Band, Besuch von zwei zivilen Offizieren der Army. In seiner Eigenschaft als Frontman der Band wandte sich Michael Franti an die Öffentlichkeit. Er schilderte Andrew Strickman vom Rolling Stone den Vorfall wie folgt: 
"She'd spoken in an interview about her daughter who has been deployed in the Gulf, and her son who is in this band Spearhead. They showed her a picture of her son wearing a t-shirt that said >Unfuck the world « on the front and >Dethrone the Bushes< on the back. They told her that was an unAmerican statement. She said, >That's free speech<, and they said, >Well, things are changing these days « (Strickman 2003).

In der amerikanischen Radioshow Democracy Now!, die von Pacifica Networks gesendet wird, ging Franti weiter ins Detail:

»They [...] said you have a child who's in the gulf and you have a child who's in this band Spearhead who's part of the sresistance< in their words, and they had pictures of us performing the day before at the rally, they had pictures of us performing at some of our annual concerts that we put on that are in support of peace and human rights. They had his flight records for the past several months, they had the names of everybody who works in [...] our management office. They had his checking account records. They asked his mother a lot of questions about where he was, what he was doing in this place, why he was going here. [...] They [were basically] intimidating - told her which members of the press she could talk to and which members of the press she should not speak to « (Goodman 2003).

Selbst Franti, der sich gegen sexuelle Gewalt und für die Aids-Aufklärung einsetzt und seit fast einem Jahrzehnt mit musikalischen Inhalten an soziale Grenzen stößt, muss angesichts einer solchen Vorgehensweise unwohl geworden sein. Im Rolling Stone reflektierte er die Ereignisse der letzten Tage und sah der Zukunft mit wachsender Sorge entgegen:

"It kind of put a scare into all of us. The fact that people would be paying this close attention to what we're doing as musicians is a bit freaky. We're human rights workers - we don't believe that people should be killed. We're not about wanting to overthrow the government, but we want to speak out. [...] I don't think that Spearhead is under investigation, or any other artist is. But people who are doing human rights work are creating little blips on the radar. And they're now investigating everyone whose views are contrary to the policies of the Bush administration. Hopefully it doesn't amount to anything more that that... hopefully« (Strickman 2003).

\section{Memos und Unstimmigkeiten bei MTV}

Neil Strauss berichtete in der New York Times vom 26. März 2003 von einem Memo des Musiksenders MTV Europe, das zu Kriegsausbruch im Irak durch das Broadcast Standards Departments des Senders an seine Mitarbeiter 
ausgegeben wurde. Mark Sunderland, einer der Manager, zitierte darin den programme code der britischen Independent Television Commission (ITC) ${ }^{1}$ und empfahl, Musikvideos, die Soldaten, Kampfjets, Bomben, Aufstände und sozialen Unruhen oder anderes offensichtlich heikles Material enthielten, bis auf weiteres nicht zu senden. Das Memo nannte konkrete Beispiele und fasste den jeweiligen »problematischer Inhalt « in einer Zeile zusammen. Darunter waren unter anderem folgende Videos:

\begin{tabular}{|c|c|c|}
\hline Band & Titel & Problematischer Inhalt \\
\hline System of a Down & $»$ Boom!« & $\begin{array}{l}\text { "anti-war video containing facts } \\
\text { and figures about, amongst other } \\
\text { things, the projected casualties } \\
\text { in the war in Iraq" }\end{array}$ \\
\hline Aerosmith & $\begin{array}{l}\text { "Don't Want To } \\
\text { Miss A Thing « }\end{array}$ & $\begin{array}{l}\text { "Contains footage from the film } \\
\text { >Armageddon«« }\end{array}$ \\
\hline Manic Street Preachers & "So Why So Sad« & $\begin{array}{l}\text { "Contains footage of soldiers } \\
\text { being killed and man throwing a } \\
\text { hand grenade }\end{array}$ \\
\hline Passengers/U2 & »Miss Sarajevo« & $\begin{array}{l}\text { "Contains missiles, guns and } \\
\text { buildings being blown up« }\end{array}$ \\
\hline Bon Jovi & $\begin{array}{l}\text { »This Ain't A Love } \\
\text { Song « }\end{array}$ & $\begin{array}{l}\text { "Contains war scenes and victims } \\
\text { in distress" }\end{array}$ \\
\hline Iggy Pop & $»$ Corruption « & $\begin{array}{l}\text { "Contains wars, riots, guns and } \\
\text { captions ' we love guns ' and 'we } \\
\text { love rifles « }\end{array}$ \\
\hline Radiohead & »Lucky« & $\begin{array}{l}\text { "Contains war footage including } \\
\text { injured children« }\end{array}$ \\
\hline Billy Idol & $»$ Hot In The City« & "contains an atomic explosion« \\
\hline Armand van Helden & »Koochy« & $\begin{array}{l}\text { "Contains an atomic explosion } \\
\text { and ships being blown up« }\end{array}$ \\
\hline Radiohead & $»$ Invasion« & "song title may offend« \\
\hline
\end{tabular}

Tabelle: Beispiele für Videos, die MTV für problematisch erklärte (zit. n. http://www.internalmemos.com/memos/memodetails.php?memo_id=1424)

Außerdem sollten alle Bezüge auf die Band B-52s konsequent gemieden werden. Frontmann Fred Schneider erklärte leicht perplex:

"I guess MTV doesn't have a research department, because from day one we've said in interviews that our name is a slang term for the bouffant hairdo Kate and Cindy used to wear - [it has] nothing to do with bombers." (Strauss 2003).

1 Die ITC wurde durch den Broadcasting Act 1990 ins Leben gerufen und lizensierte und regulierte über ein Jahrzehnt lang die kommerziellen TV-Stationen des Vereinten Königreichs. Im Dezember 2003 wurden ihre Aufgaben dem Office of Communications, einer zentralen Medienaufsichtsbehörde, übertragen. 
Diese Form der Zensur eines Senders in Großbritannien wirkt sich auf zahlreiche Länder Europas aus, denn jedes europäische Land, das keinen eigenen MTV Ableger hat, empfängt automatisch MTV Europe, das in London produziert wird und damit genau wie MTV UK der Aufsicht der ITC bzw. seit 2003 dem Office of Communications untersteht. Wenn also MTV Europe Äußerungen zum Krieg in jeder Form aus dem Programm nimmt, bekommen auch die Zuschauer dieser europäischen Länder die entsprechenden Videos nicht zu Gesicht. Derzeit sind etwa 19 Staaten von dieser Regelung betroffen.

Eine Pressesprecherin des Muttersenders in den Vereinigten Staaten erklärte Strauss (2003), dass das Memo nur für MTV Europe gelte. Sie unterstrich, dass es auch dort kein generelles Verbot gebe, die Videos zu senden, und dass das Memo lediglich eine Empfehlung sei. Nichtsdestotrotz handelte es sich um eine sehr dringliche Empfehlung, denn mit Einschüben wie "Please note that this is not a definitive list of videos. Please use the ITC video restrictions database to check each song before broadcast « drängte das Memo Sunderlands vielfach unterschwellig, dem Aufruf Folge zu leisten (vgl. http://www.internalmemos.com/ memos/memodetails.php?memo_id= 1424). Die Sprecherin des amerikanischen Senders gab des Weiteren bekannt, dass MTV auch in den Vereinigten Staaten »responsive to the heightened sensitivities of its audience « agiere (Strauss 2003).

Ihr Kollege Graham James hingegen betonte Joe Garafoli gegenüber die Unparteilichkeit MTVs und deutete an, dass man nie vorgehabt habe, das Dokument umzusetzen:

»There is absolutely no MTV policy anywhere in the world banning warrelated music videos. The memo was only a recommendation from a staffer and was not and will not be implemented. It was ludicrous. In the U.S. and everywhere, all voices have been and will continue to be heard on MTV« (Garafoli 2003).

Die von Russell Simmons und Mos Def kreierten "anti-war public-service commericals« wurden dennoch abgelehnt. MTVs Presseabteilung bestätigte dies und schrieb, dass MTV »advocacy ads« nicht akzeptiere (Strauss 2003). Unter diesen Umständen stellt sich freilich die Frage, wie die »recruiting ads« der Navy dann zu jeder Tages- und Nachtzeit auf MTV zu sehen sein konnten.

Über einen ähnlich inkohärenten Sachverhalt wunderte sich Michael Franti. Democracy Now! Moderatorin Amy Goodmann erzählte er Folgendes: »Last week our label received a letter, a mass e-mail from MTV instructing the fact that no videos could be shown that mentioned the word bombing or 
war. [...] Yet MTV has aired videos that show troops saying goodbye to their loved ones and going off to war in a very heroic fashion« (Goodmann 2003).

\section{Die System of a Down-Kontroverse}

Auch System of a Down, seit langem politisch engagiert, protestierten mit ihrer Single »Boom! « gegen den drohenden Krieg. Die Regie des Videos übernahm Michael Moore. Auf der offiziellen Website der Band erläuterte er den Grund für das gemeinsame Projekt:

»The strangest thing about this impending war is that the people - the real majority who make up the population of this country and the world - do not truly want to go to war. Watching the news, you would never know that millions have been out there proposing a different solution, one that does not involve the slaughter of innocents. It is these people whom we will give voice to in >BOOM! « (http:/ / www.systemofadownonline.com/vid/boom.htm).

Das Video selbst ist ein Zusammenschnitt von Bildern von über vierzig Friedensdemonstrationen, die am 15. Februar stattfanden. Es beginnt mit den Worten:

»On February 15, 2003, ten million people in over 600 cities around the world participated in the largest demonstration in the history of the world. Because we choose peace over war, we were there too."

Im Video sind riesige Menschenmassen zu sehen. Demonstranten halten Plakate hoch auf denen »Listen To The World« und »No, Mr. Bush« zu lesen ist und protestieren mit Aussagen wie »We don't believe the lies that are fed to us through the media « gegen die Informationspolitik am Vorabend der Invasion. Viele sprechen Teile des Textes nach:

Modern globalization, coupled with condemnations

Unnecessary death, matador corporations

Puppeting your frustrations with a blinded flag

Manufacturing consent is the name of the game

The bottom line is money, nobody gives a fuck

In seinen Zwischenschnitten zeigt das Video zerfetzte Friedenssymbole, Kampfjets und Explosionen. Headlines verschiedener Zeitungen tauchen in Untertiteln auf:

»Halliburton wins contract to rebuild Iraqi oil fields«, »Iraqi oil reserves worth $\$ 4$ Trillion«, »War to cost U.S. \$70 - \$200 Billion«, »1 in 6 U.S. children 
live in poverty«, »Pentagon orders 77,000 body bags«, »One congressmen with a child in the military«.

Alle diese Schlagzeilen werden in der News-Section der offiziellen System of a Down-Website Punkt für Punkt ausführlich und mit Quellenangaben zitiert.

Trotz Michael Moores Engagement stieß das Video in vielen Musiksendern auf Ablehnung. Hier waren sich die Firmen auch innerhalb ihrer Divisionen selten einig. Serj Tankian, Sänger der Band, berichtete der New York Times, dass MTV USA das Video zeitweise spielte, während MTV UK und MTV Europe dies aufgrund des Memos nicht taten. Das Musikvideonetzwerk MuchMusic agierte ähnlich und zeigte das Video in Kanada, nicht aber in den Vereinigten Staaten (Strauss 2003).

\section{Clear Channel und die Bush Administration}

Der Medienkonzern Clear Channel Communications kontrollierte im März 2003 über 1.200 Radiostationen der USA und erreichte jede Woche 54\% Prozent aller Amerikaner auf seinen Frequenzen (Petridis 2003). Die zweitund drittgrößten Konzerne folgten mit 270 beziehungsweise 80 Stationen weit abgeschlagen. Clear Channel war im Irakkrieg für zahlreiche Boykotts und Pro-Kriegs-Kampagnen verantwortlich, will aber von einer zentralen Organisation dieser Parteinahme nichts wissen. Paul Krugman beobachtet in der New York Times vom 25. März 2003:

»The company claims that the demonstrations, which go under the name Rally for America, reflect the initiative of individual stations. But this is unlikely: [...] the company is notorious - and widely hated - for its ironfisted centralized control« (Krugmann 2003).

Krugmans Vermutung gewinnt weitere Plausibilität, denkt man an die schwarze Liste von 150 Songs, die nach den Anschlägen vom 11. September zwischen den Stationen des Clear Channel-Netzwerks zirkulierte (s. S. 60f.). Er führt weiter aus:

»Until now, complaints about Clear Channel have focused on its business practices. Critics say it uses its power to squeeze recording companies and artists and contributes to the growing blandness of broadcast music. But now the company appears to be using its clout to help one side in a political dispute that deeply divides the nation« (ebd.).

John Ivey, Vice President of Programming bei Clear Channel, erklärte gegenüber der Los Angeles Times in einer ersten Reaktion: »| don't think that anybody is looking to fill up the airwaves with songs about the war « 
(zit. n. Kot 2003). Offenbar wurden sie lieber mit Pro-Kriegs-Songs verstopft: Daniel Worleys »Have You Forgotten?«, das angeblich als eine mahnende Stimme an den 11. September erinnere, lief beispielsweise auf Heavy Rotation (ebd.).

Es gibt zahlreiche Indizien, die darauf hindeuten, dass sich der Konzern aus guten Gründen in die Politik einmischt. Clear Channel will weiter expandieren und ist auf das Wohlwollen der Regierung angewiesen. Die Konzentration der 1.200 Stationen wurde erst nach einer Gesetzesänderung durch die Federal Communications Commission, kurz FCC, möglich, der die Rundfunkaufsicht unterliegt. ${ }^{2}$ Immer mehr Politiker haben sich jedoch in der Vergangenheit für die Aufhebung der Erlaubnis ausgesprochen - nicht zuletzt, weil Clear Channel sich in einem langen Rechtsstreit für seine »business practices « verantworten muss. Angeblich hat der Konzern diversen Musikern, die nicht mit der Clear Channel Concert Division touren wollten, gedroht, das Airplay ihrer Songs zu beschneiden (Krugman 2003). Krugman spürte weitere Verbindungen zwischen Clear Channel und der Bush-Administration auf:

»Experienced Bushologists let out a collective >Aha! $<$ when Clear Channel was revealed to be behind the pro-war rallies, because the company's top management has a history with George W. Bush. The vice chairman of Clear Channel is Tom Hicks [...]. When Mr. Bush was governor of Texas, Mr. Hicks was chairman of the University of Texas Investment Management Company, called Utimco, and Clear Channel's chairman, Lowry Mays, was on its board. Under Mr. Hicks, Utimco placed much of the university's endowment under the management of companies with strong Republican Party or Bush family ties. In 1998 Mr. Hicks purchased the Texas Rangers in a deal that made Mr. Bush a multimillionaire« (Krugmann 2003).

George Bush wurde in seinem Wahlkampf von Clear Channel tatkräftig unterstützt (Williamson 2003). Es ist davon auszugehen, dass zwischen Regierung und Medien weitere private wie finanzielle Verbindungen bestehen (Kot 2003; Krugman 2003).

2 Möglich machte die Änderung unter anderem der damalige Chief of Staff der Antitrust Division, der Kartellbehörde des US-amerikanischen Justizministeriums, Michael Powell im Telecommunications Act von 1996 (Wailand 2003). Powell ist Sohn des Außenministers des Bush-Kabinetts, Colin Powell. 1997 wurde er von Präsident Bill Clinton zu einem Commissioner, 2001 durch Bush zum Chairman der FCC befördert (vgl. www.fcc.gov/commissioners/powell/ mkp_biography.html). 


\section{Ein Schock für die Dixie Chicks}

In einem derart konservativ geprägten Klima löste die kritische Haltung der texanischen Dixie Chicks eine mediale Hetzkampagne aus. Als die bis dahin erfolgreichste Countryband wenige Tage vor der offiziellen Kriegserklärung der alliierten Staaten an den Irak ein Konzert im Londoner Sheperd's Bush Empire gab, bemerkte Natalie Maines: »Just so you know, we're ashamed the president of the United States is from Texas « und erntete Applaus beim britischen Publikum. Die Journalistin Betty Clarke (2003) griff dieses Zitat in ihrer Kritik im Guardian auf. Der Artikel verbreitete sich über Websites und Newsgroups und erreichte einige Tage später die amerikanischen Massenmedien. Der Radio-Trust Clear Channel reagierte sofort und verbannte die Songs der Dixie Chicks "out of respect for our troops and our listeners « aus den Ätherwellen seines Einflussbereichs. Cumulus Media und Cox Radio, die zweit- und drittgrößten Radionetzwerke der USA, taten es Clear Channel gleich. Man behauptete, die Stationen hätten die Band unabhängig voneinander und lediglich auf Verlangen der Hörer aus den Playlists gestrichen (Lee 2003). In unmittelbarer Folge dieser Radioabstinenz schrumpften die Verkaufszahlen des aktuellen Albums der Band, Home, in dieser Woche von 124.000 auf 33.000. Ihre Hitsingle »Travelin' Soldier", die bis dahin Platz eins belegt hatte, fiel ungebremst die Charts hinunter. Die Presse brandmarkte das Trio als "unamerikanisch « und "unpatriotisch « und denunzierte die Band als "Dixie Sluts«, "Traitors" und "Saddam's Angels" - letzteres, obwohl sich keines der Bandmitglieder je für Saddam Hussein ausgesprochen hatte (Williamson 2003). Geschockt zog Natalie Maines die Notbremse und entschuldigte sich öffentlich. Ihr Statement postete sie auf der offiziellen Bandwebseite:

"As a concerned American citizen, I apologize to President Bush because my remark was disrespectful. I feel that whoever holds that office should be treated with the utmost respect. We are currently in Europe and witnessing a huge anti-American sentiment as a result of the perceived rush to war. While war may remain a viable option, as a mother, I just want to see every possible alternative exhausted before children and American soldiers' lives are lost. I love my country. I am a proud American« (http:// dixiechicks.launch.yahoo. $\mathrm{com} /$ news.asp?id=26).

Maines Beteuerung verhallte im leeren Raum. Die CDs der Dixie Chicks wurden bei eigens organisierten Events im ganzen Süden und mittleren Westen der USA verbrannt; in Louisiana setzte KRMD, ein Countrysender, der zu Cumulus Media gehört, einen Traktor zur Zerstörung der aufgehäuften 
Platten ein (Krugman 2003). In Colorado Springs suspendierte Jerry Grant, Manager des unabhängigen Radiosenders KKCS, zwei seiner DJs, nachdem sie sich über den offiziellen Boykott der Band hinweggesetzt hatten. In einer Stellungnahme erklärte Grant:

»They [the station's DJs Dave Moore and Jeff Singer] made it very clear that they support wholeheartedly the president of the United States. They support wholeheartedly the troops, the military. But they also support the right of free speech. I gave them an alternative - stop it now and they'll be on suspension, or they can continue playing them and when they come out of the studio, they won't have a job « (Associated Press v. 6.5.2003, zit n. http://www.polarity1.com/pcrr50.html).

Natalie Maines erhielt Morddrohungen und wurde rund um die Uhr von bewaffneten Sicherheitsleuten bewacht. Auch Martie Maguire und Emily Robison, die sich mit ihrer Bandkollegin solidarisch gezeigt hatten (»Natalie's comment came from frustration that we all shared«; Campbell 2003), bekamen das allgemeine Ressentiment zu spüren: Maguires Chauffeur quittierte seinen Dienst, Robison's Ranch wurde von unbekannten Kriegsbefürwortern in eine Mülldeponie verwandelt. »It seems unfathomable that someone would not want to drive us because of our political views «, bezog Maines Stellung. »But we're learning more and more that it's not that unfathomable to a large percentage of the population« (ebd.).

Als die Tour der Dixie Chicks wenige Wochen später startete, wurden die Shows mit Bruce Springsteens »Born In The USA und Elvis Costellos Version von »(What's So Funny 'Bout) Peace, Love And Understanding « eingeleitet. Im weiteren Verlauf der Konzerte sprach Maines den kontroversen Zwischenfall in London an und stellte einen Song namens »Truth No. 2 « vor. Dieser begann mit den Zeilen:

You don't like the sound of the truth coming from my mouth

You say that I lack proof, well baby that might be so

I might get to the end of my life, find out everyone was lying

don't think that I'm afraid anymore say that I would rather die trying

Zu diesem Song erschienen auf einer Videowand hinter der Band Bilder von Martin Luther King, Mahatma Gandhi und diversen Protestversammlungen der Bürgerrechtsbewegung. Dazwischen geschnitten waren die fordernden Worte »Stop - Look - Listen«. Es folgten Fotos der Bücherverbrennungen durch die Nationalsozialisten, die Aufnahmen der verschmorten und zermalmten Dixie Chicks-CDs gegenübergestellt wurden. Am Ende des Songs wurden als stumme Appelle die Worte »Seek the Truth « und »Tolerance eingeblendet (Williamson 2003). 
Besonders Clear Channel scheute keine Mühen, das Publikum von den Konzerten der Band fern zu halten. Der Konzern war anscheinend der Ansicht, dass die Shows des Trios seinen Interessen nicht dienlich sein würden. So wurden parallel stattfindende Konzerte organisiert, zu denen man Inhabern eines gültigen Dixie-Tickets freien Zutritt gewährte (Sharma 2003).

Im Rahmen eines Hearings zur Zukunft der Radioindustrie sprach sich Simon Renshaw, Manager der Dixie Chicks, vor dem Kongress gegen die weitere Lockerung des Telecommunication Acts aus. Er berichtete von der Kampagne gegen die Dixie Chicks und bestätigte, dass auch sein Büro Morddrohungen erhalten habe, die gegen Maines gerichtet waren. Die Rechte, die das First Amendment der US-amerikanischen Verfassung der Band garantiert, seien missbraucht worden und hätten so »artistic freedom, cultural enlightenment and political discourse (Campbell 2003) untergraben:

»What happened to my clients is perhaps the most compelling evidence that radio ownership consolidation has a direct negative impact on diversity of programming and political discourse over the public airwaves« (Lee 2003).

Einige Mitglieder des Komitees stimmten zu. Barbara Boxer, eine demokratische Senatorin des Staates Kalifornien, verglich die Ereignisse mit den anfänglichen Bemühungen des Naziregimes sowie den Hexenjagden der McCarthy-Ära und nannte sie »a chilling message to people that they ought to shut up « (ebd.). Das Weiße Haus in Washington hingegen sah keinerlei Anlass zur Besorgnis und bestärkte die Band damit in ihrer Überzeugung, dass es notwendig sei, sich kritisch zu äußern. Im Interview mit Nigel Williamson erinnerte sich Maines:

»We were told the official White House quote on our ordeal. I thought it was going to be something empowering about the first amendment and our rights as American citizens. I don't know why I thought such an educated thing could have come out of there. Instead it was, >Their fans have spoken«" (Williamson 2003).

\section{Die Grammy Awards}

Es hätte die größte Anti-Kriegs-Kundgebung überhaupt werden können. Mit Sheryl Crow, Chris Martin, Fred Durst und Bonnie Raitt waren bei der Verleihung der Grammy Awards viele der ganz Großen des Mainstream präsent, die sich wiederholt gegen einen Krieg im Irak stark gemacht hatten - doch sie alle blieben seltsam stumm. 
Chris Martin, der noch drei Tage zuvor einen Brit Award mit den Worten »Awards are essentially pointless since we're all going to die if George Bush has his way [...] but thanks « akzeptiert hatte, verlor kein Wort über den drohenden Krieg, als er mit Coldplay für A Rush Of Blood To The Head den Grammy für das beste »Alternative Album« erhielt. Als Hosts wagten Bonnie Raitt und Fred Durst kaum von ihren Scripts abzuweichen. Raitt machte lediglich eine kleine Anspielung auf einen möglichen Frieden und Durst bemerkte: "I think we're all in agreeance that we want this war to be over as quickly as possible « (Petridis 2003). Unmittelbare Reaktionen auf diesen diplomatisch formulierten Einschub blieben aus. Der britische Chefredakteur des US-Rockmagazins Blender, Andy Pemberton, zeigte sich irritiert: »That was a pretty equivocal statement, but no one seemed interested in exactly what Durst had meant. All anyone seemed interested in was whether sagreeance « was a proper word or not « (ebd.). Sheryl Crow hingegen äußerte sich nicht vokal, sondern visuell. Die Sängerin trug ein großes PeaceZeichen um den Hals und ihr Gitarrengurt verkündete »No War «.

Die plötzliche Verschwiegenheit hatte einen einfachen Grund: CBS und die National Academy of Recording Arts and Sciences hatten allen Mitwirkenden den Mund verboten. Als Organisatoren der Grammies hatte die National Academy of Recording Arts and Sciences das Verbot veranlasst und die CBS, die für die Fernsehübertragung der Awards zuständig war, hatte am selben Strang gezogen und den Musikern mitgeteilt, dass bei jedem Versuch einer kritischen Äußerung die Mikrofone sofort stumm geschaltet würden. Ein Akt der Zensur, den Coldplay-Drummer Will Champion später als »absolutely disgusting - foul and totally fascist « beschrieb (ebd.). Obwohl auch Sheryl Crow, Fred Durst und Bonnie Raitt von dem Verbot berichteten, bestritten CBS und Grammy Komitee die Vorwürfe (Pareles 2003). Die New York Post rief nach den Grammies zum Boykott von Sheryl Crow und Fred Durst auf. Man solle ihre Konzerte meiden und die Platten nicht kaufen (Wailand 2003).

Wie Paul Krugman (2003) es formulierte: »There's something happening here. [...] In the Bush administration, government and business have melded into one big >us.« Es lässt sich festhalten, dass die Medien unerwünschte Meinungen systematisch auszublenden versuchten. Von wenigen Ausnahmen abgesehen gelangten kaum kritische Songs über Radio oder Fernsehen an die Öffentlichkeit. R.E.M.s Mike Mills äußerte frustriert: »Thank God for the Internet, because we're fighting against a corporate culture that makes it practically impossible to get a protest song on the air« (Kot 2003) und Michael Franti erklärte in Democracy Now!: 
»Look at the way all of these songs have been put out in opposition to the war: the Beasties, Lenny Kravitz, Zack de la Rocha, R.E.M... Labels are afraid to put those out as singles and bring them to the radio stations out of fear for what happened to the Dixie Chicks. Now it's coming to the internet, which is great. But it's unfortunate that we live in a time and in a country where radio is so centralized and under the control of so few voices. Our musical heroes all spoke to the times, but this time around we're not able. Not in the same way« (Goodman 2003).

Die unter dem Label des »Unamerikanischen « eingeleiteten Untersuchungen im Falle von Spearhead und den Dixie Chicks, die Boykotts und CD-Verbrennungen erinnern stark an die McCarthy-Ära. Emily Robison, Gitarristin der Dixie Chicks, sieht in den Schlagworten »unamerikanisch « und »unpatriotisch« eine nicht zu unterschätzende Gefahr:

»They've set this tone that they're not to be questioned and if you do then you are unpatriotic. That's somehow gotten into the American psyche and that's scary. If you can't question your government then you are just mindless followers« (Williamson 2003).

Die politische Situation vor und während des Irakkriegs lässt sich mit den Untersuchungen vermeintlich kommunistischer Umtriebe zu Beginn der 1950er Jahre vergleichen, die mit dem Namen des Senators Joseph McCarthy verbunden sind. Während die amerikanische Bevölkerung nach dem zweiten Weltkrieg den Kommunismus und die Massenvernichtungswaffen Russlands fürchtete, galt diese Besorgnis nach den Anschlägen vom 11 . September dem Terrorismus und den Massenvernichtungswaffen des Irak. In beiden Fälle diente die massiv geschürte, diffuse Angst vor einer nur schwer zu konkretisierenden Bedrohung zur Durchsetzung politischer und wirtschaftlicher Interessen auf Kosten der freien Meinungsäußerung und der Meinungsvielfalt - nicht nur in der populären Musik.

\section{Literatur}

(Letzter Zugriff für alle Internetadressen: 17. Juli 2004)

Campbell, Duncan (2003). »>Dixie Sluts Fight on with Naked Defiance«. In: Guardian, 25. April (http://www.guardian.co.uk/arts/war/story/0,12958, 943433,00.html).

Clarke, Betty (2003). »The Dixie Chicks.«In: Guardian, 12. März (http://www. guardian.co.uk/arts/reviews/story/0,11712,912236,00.html).

Epstein, Dan (2003). "Sing Now, or Forever Hold Your Peace." In: LA Weekly, 14.20. Februar (http://www.laweekly.com/ink/03/13/music-epstein.php). 
Garafoli, Joe (2003). "Artists React to Tale of Intimidation.« In: San Francisco Chronicle, 5. April (http://sfgate.com/cgi-bin/article.cgi?file=/chronicle/ archive/2003/04/05/BA74262.DTL).

Goodman, Amy (2003). Democracy Now! Gesendet am 27. März 2003 über Pacifica Network.

Kot, Greg (2003). „Conflict Prompts Outpouring of Politics, Protests from Musicians. «In: Chicago Tribune, 23. März (http://www.chicagotribune.com/features/ arts/chi-0303230396mar23,1,4273423.story?coll=chi\%2Dleisurearts\%2Dhed).

Krugmann, Paul (2003). „Channels of Influence.«In: New York Times, 25. März (http:://www.nytimes.com/2003/03/25/opinion/25KRUG.html).

Lee, Jennifer (2003). »Musicians Protesting Monopoly in Media.« In: New York Times, 18. Dezember (http://www.nytimes.com/2003/12/18/arts/music/ 18MEDI.html).

Pareles, Jon (2003). „New Songs, Old Message: >No War «. In: New York Times, 9. März (http://www.nytimes.com/2003/03/09/arts/music/09PARE.html).

Petridis, Alexis (2003). "Sound of Silence«. In: Guardian, 14. März (http://www. guardian.co.uk/arts/war/story/0,12958,916037,00.html).

Sharma, L.K. (2003). »Dixie Chicks Booed, Snubbed, Censored.«In: Deccan Herald, 23. Mai (http://www.deccanherald.com/deccanherald/may23/i5.asp).

Strauss, Neil (2003). »MTV Is Wary of Videos on War. «In: New York Times, 26. März (http://www.nytimes.com/2003/03/26/arts/music/26POPL.htm).

Strickman, Andrew (2003). "Army questions Spearhead Mom. «In: Rolling Stone, 3. April (http://www.rollingstone.com/news/newsarticle.asp?nid=17846\&afl= mnew).

Wailand, Markus (2003). »Kunst gegen Krieg.« In: Falter, Nr. 16 (http://www. falter.at/print/F2003_16_2.php).

Williamson, Nigel (2003). »Free the Dixie Three.«In: Guardian, 22. August, S. 7-8.

\section{Abstract}

The closer the outbreak of the war against Iraq came the stronger the government and government friendly media in the US but also in the UK tried to silence oppositional voices. This article recounts some of the most prominent cases of direct and indirect censorship: The threatening of the families of members of the band Spearhead by army officers, the campaign against the Dixie Chicks, the case of System of a Downs' Single and Video »Boom! «, Clear Channel's censorship of »unamerican« musicians and its links with the US government, and the silencing of critical voices during the broadcast of the Grammy Awards 2003. 